\title{
DOES SUSTAINABILITY MATTER IN MERGERS AND ACQUISITIONS? THE CASE OF THE SERBIAN FOOD INDUSTRY
}

\author{
Ksenija Denčić-Mihajlov ${ }^{l}$ \\ *Corresponding author E-mail: ksenijadm@gmail.com
}

\begin{abstract}
A R T I C LE IN F O
A B S T R A C T

Original Article

This paper investigated key areas in which environmental, Received:06 December 2019

Accepted: 18 February 2020 social and governance issues may be important in M\&A transactions, with a particular emphasis on the Serbian food industry. The analysis was conducted using a sample doi:10.5937/ekoPolj2001025D

UDC 631.564:338.439(497.11)

Keywords:

Mergers and acquisitions, sustainability, Serbia, foodprocessing industry of 11 realized M\&As in the Republic of Serbia with the food producers as target companies and is based on the data acquired from the targets' annual reports and web sites. The analysed transactions, that have been randomly elected, belong to different legal types of M\&A: acquisition of asset, acquisition of shares, tender offer and merger/consolidation. Following the classification of sustainability issues, two types of M\&A in the Serbian food industry have been distinguished: one enables the JEL: G34, G32, M14, Q56 acquirer to build the presence in the key segments with sustainability products in line with modern health trends, while the other helps the buyer to improve synergies and consolidate leadership position by acquiring target with a recognized sustainability profile and credibility.
\end{abstract}

(C) 2020 EA. All rights reserved.

\section{Introduction}

Mergers and acquisitions (M\&A), as transactions characterized by a consolidation of companies or assets through different types of financial transactions, are an increasingly important factor of the modern economic activity. The scope and far-reaching consequences of mergers and acquisitions strategy in capital, labor, product and service markets of the companies involved in M\&As is described by the fact that in 2018 the total value of transactions on a global level was $\$ 4,073$ trillion and that the total number of M\&A reached 52.009 (IMMA Report, 2019). According to the UNCTAD data (2018), the total value of foreign direct investments during 2017 reached $\$ 1,42$ billion while the value of cross-border M\&A took part in this value with a very high amount of $\$ 0,86$ billion.

Considering nowadays international orientation of the companies, and the continuous

1 Ksenija Denčić-Mihajlov, Ph.D., Full Professor, University of Niš, Faculty of Economics, Trg kralja Aleksandra Ujedinitelja 11, 18000 Niš, Serbia, Phone: +381 18528 687, E-mail: ksenijadm@gmail.com ORCID ID (https://orcid.org/0000-0002-2419-0676)

http://ea.bg.ac.rs 
process of integration in global markets, a further growth trend of M\&A activity is expected in the upcoming time. Future period will certainly bring new challenges for the implementation of M\&A strategy, such as changing regulatory requirements, the change of needs and consumer habits, new risks that companies face in implementing the chosen strategy of growth and development, and in particular, computerization and the digital transformation (see Denčić-Mihajlov, Spasić, 2018). A changing and complex business environment forces companies to respect the requirements for sustainability management and to build carefully their external growth strategies in order to realize and maintain competitive advantage over the long term. With the awareness of importance of environmental consequences and sustainability, market value in the post-acquisition period is no longer determined by single financial performance indicators.

Even though including sustainability consideration in the M\&A transactional matrix could release the potential value of sustainability, reduce the possible faults and therefore lead to better strategic investment decisions, these external growth strategies have been for a long time uninfluenced by the "green trend". Still, realized transactions during the last years, initiated by a spectrum of factors, have indicated that sustainability consideration can help in increasing the value of M\&A deals. Regulatory changes, environmental and reporting requirements, digitalization as well as the emergence of new risks in the corporate environment, are among others, the factors that have influenced incorporation of sustainability consideration into M\&A process the most.

New regulation requirements, enforced by the governments (but also at local levels), come as a reaction to shareholders concerns about natural resources and the environmental and social impact of business activities. Along with the strengthening of environmental regulations, companies deal with growing demand for information about their environmental liabilities. In light of this, it's important for both buyers and sellers in M\&A deals to understand the scope and impact of new regulation requirements on the structure, execution, and value of the deals. "A number of regulatory bodies have worked and are still working on establishing guidelines and standards for sustainability reporting in order to achieve a higher level of harmonization throughout the world" (Dencic-Mihajlov, Stojanovic-Blab, 2017).

Digital economy is becoming an increasingly important factor in modern global business. Regardless of the strategic vision of the company, it is certain that the M\&A decisions in the future are to be made in the digital world, companies will need to effectively handle the large amount of information and use such information for M\&A activities faster than ever. A wide range of investors already make investment decisions using digital assessment tools that link sustainability issues with corporate performance. However, even though new digital technologies lead to sustainable innovations and improve sustainability performances, they could generate new vulnerabilities (such as cybercrime and the loss of privacy).

As stated in the Global Report on Risk Management (World Economic Forum, 2016), the inability and failure to understand the economic risks and the lack of application 
of instruments to manage risks associated with the technology, the company and environment, can have far-reaching consequences on the intensity of realization and efficiency of the implementation of external growth strategies, especially in an international context. New risk that have emerged last years force companies that intend to pursue M\&A to respect the requirements for sustainability management in order to achieve and maintain competitive advantage over the long term.

The environmental, social and governance (ESG) issues may play part in M\&A transactions in several areas, such as (1) selection of target company, (2) due diligence process, (3) deal valuation and (4) post-acquisition integration. From sustainability perspective, a purpose of due diligence is to supply the acquirer with adequate information to make decision on investment in external growth. Having understood and incorporated all the identified risks, the buyer valuates the deal. Incorporating sustainability issue in valuation process supposes not only direct impacts (for example, cost savings resulting from energy efficiency or growth of profits achieved with sustainable products), but also indirect effects (manifested in improved reputation, employee engagement or customer loyalty). However, according to survey made by PwC (2012), in practice, few companies currently measure the value that they are generating from management of sustainability factors. The valuation process has to take into account all the costs of post-acquisition integration together with the potential costs resulting from the increased risk reflected in the bid (the incurred costs due to more comprehensive covenants or to target's withdrawal from the transaction). As stated in Deloitte report (2008) on the role of sustainability in M\&A, due to still evolving sustainability metrics, the evaluation of a target company's sustainability activities should incorporate much more than the "target's public claims regarding carbon output reduction, lowering of energy use, or other sustainability successes". Seller company could be too aggressive or too conservative while representing its sustainable activities. Therefore, an acquiring company, during valuation process, should investigate the target's processes and controls that support such claims.

In the post-acquisition period, the acquiring company has to plan the activities directed to quick and efficient improvement of sustainability efforts of the combined entity. The acquirer is proposed to determine the request towards target in regard with disclosure of sustainability performance in order to unify performance on ESG factors according to its own standards.

During the past decades the topic of M\&A has been extensively studied from the different aspects such as motivation, determinants, value creation, payment methods as well as behavioural, organizational and cultural aspects (for an updated literature review see: Caiazza, Volpe, 2015). Despite the enormous importance given to M\&A transactions in the framework of growth and value creation, only a few studies tackle the process of M\&A structuring in the context of sustainability. More recently, and not unexpectedly, researches have been focusing on some of the "sustainability factors relating to before-during-and-after M\&A process" (see: Hečkova et al., 2019). Isolated examples of researches of the sustainability in M\&A in the food industry are studies 
done by Schmidt-Riediger (2008), Manocha et al. (2016), Bonny (2017) and Clapp (2018). The aim of the paper is to investigate key areas in which environmental, social and governance issues may be important in M\&A transactions. This paper's contribution is in identifying the key theoretical and practical issues relevant when assessing and incorporating sustainability within the M\&A process in the food industry.

\section{Materials and methods}

Selection of target company and due diligence process, as stated before, are two crucial areas in M\&A realization, where sustainability issues should be thoroughly taken into account. An acquiring company that takes into account ESG issues may add value to its shareholders if in selection process look for a target with well-developed, sustainable business. This would enable the acquirer to obtain expertise and experience to increase business efficiency. In the opposite case, as highlighted by Mannheimer Swartling (2017), by selecting a target which operations are related to "the risk of severe contamination, demands for emission reductions, direct or indirect violations of human rights, poor working conditions or the risk of corruption", could result in negative publicity and increase of integration costs. The sector in which target operates plays also a significant role as a selection criteria, particularly if there are differences between the buyer and the target sectors' attitude towards sustainability. More precisely, the information which are subject of due diligence process are those related to (Deloitte, 2008):

- "sustainability policies;

- any external reports on the ESG status of individual portfolio companies, and of the portfolio as a whole,

- copies of any management system standard certificates as well as copies of any regulatory licences/consents, and details of any breaches,

- details of health and safety accidents/incidents,

- any evidence of governance arrangements (such as Codes of Conduct, Bribery and Corruption Policies)".

In addition to above mentioned, due diligence is dealing with the details of performance on ESG factors, using sustainable indicators where appropriate (see: Denčić-Mihajlov, Zeranski, 2017). As pointed out by Cooper (2017), since sustainability issues are getting more connected with risk mitigation, a due diligence of a potential target company that take into account target's sustainability engagement and performances is becoming increasingly relevant part of M\&A strategy planning and valuation. In line with the economics evaluation of the M\&A deal, the acquiring company should a) assess potential acquisition targets with regard to energy and water use, solid waste handling or wastewater disposal, and other environmental issues, and b) project potential expenditures related to these environmental components. 
There are three groups of risks associated to the M\&A realization. At a global level, acquiring companies are faced with risks of macroeconomic, technological, legal, socio-cultural and ecological development. At sector level, risks related to the competitors, suppliers and customers have to be considered. Finally, risks connected to potential target company (target's strategy, portfolio, location, business model) are very important in due diligence process.

Legal due diligence, as an in-depth analysis and review of corporate documents, contracts and agreements, current, future and potential litigation, environmental factors as well as legal and regulatory compliance, is critical part of M\&A due diligence process. However, the possibility of full contractual protection against sustainability risks in practice is restricted, since target company often avoids to provide guarantees related to third parties. This is particularly important in sustainability due diligence, because a lot of sustainability risks arise from the relationships and contract that target has with its suppliers and other business partners. Along with risk associated with target's operations and business, acquiring company has also to analyze and evaluate the practice of risk management in the target company. In order to have an objective picture of specific sustainability risks related to specific M\&A transaction, a comparison of target's and acquirer's risks' portfolio and risk management models is required.

One of the areas in which above discussed sustainability considerations in the process of target company selection and due diligence impact M\&A transactions most obviously is the food industry. According to consumer's behaviour studies, the sustainability in the food production gains increasing significance to consumers. With the changing business environment, the food industry faces new challenges, and strategies such as M\&A become critical for corporate success, achieving and maintaining corporate advantage. On one hand, a low growth perspectives in this industrial sector and growing demand (driven significantly by consumerism, phenomenon related with the Generation Y), create a need for M\&A realization among companies operating in food industry. In the same time, the fact that recent recession had high negative impact on this mature sector, forced food producers to maintain low prices and margins. On the other hand, these companies are faced with numerous challenges such as changing consumer priorities and motivations in relation to food purchase and consummation as well as intensifying competition from smaller, innovative oriented producers.

According to Food Dive institution (FoodDive, 2015), two most important trends in food industry that took place last years are: 1) orientation to natural components without artificial colours and flavours due to health requirements, 2) M\&A continuing to be dominant strategy in the industry. Thus, the Kraft-Heinz merger was the biggest realized M\&A transaction in the sector. Some examples of sustainable M\&A among multinational companies operating in the food sector are the acquisition of plant-based food company Sweet Earth by Nestle or the fusions between Unilever and UK ethicallysourced tea brand Pukka, Danone and the US plant-based and organic dairy business White Wave Foods, Finland's Bioferme and the food corporation Fazer Group. 
The objective of this paper is to test whether sustainability considerations are important in the M\&A deal selection assessment and execution processes in the food industry. Thus, the research questions are settled as:

RQ1: Do sustainability issues play a role in $M \& A$ in the Serbian food industry?

RQ2: What are the patterns in the field of $M \& A$ and sustainability in the case of the food processing industry in the Republic of Serbia?

In order to answer to these questions, the main characteristics of the M\&A process at the Serbian market should be primarily considered. The Serbian M\&A transactions have been influenced by the existence of narrow national capital markets with a small number of potential domestic acquirers, the presence of investment funds from tax haven countries and conglomerates as foreign acquirers, and the predominant realization of horizontal M\&A (Todorović, Denčić-Mihajlov, 2004). By comparing the volume and intensity of M\&A activity in Central and Eastern European countries, it can be concluded that M\&A activity in Serbia still lacks volumes and depths compared to these countries (during 2016 and 2017 any single large-scaled deals has not been realized). According to statistical data (Statista, 2018), the aggregate value of M\&A deals in Serbia amounted to 624.4 million euros in 2017, which is a decrease when compared to 2011 when almost two billion euros worth of deals were completed. Such a low level of M\&As in Serbia could be related to the fact that despite a slow emergence from the long recession, Serbian economy continued to growth depressed due to public spending cuts. The situation is gradually improving last years, and the economic recovery has been indicated by country's real GDP growth rate approaching 2,8\% in 2016 and 1,87\% in 2017 (World Bank Report, 2019).

Manufacturing is in Serbia the most active sector according to M\&A number and total value. As a type of manufacturing sector, Serbian food and beverage industry is one of the few sectors recording a trade surplus. According to the Development Agency of Serbia (2017), the agro-food sector accounts for a massive proportion of foreign direct investments, both in terms of value and the number of projects $(13.1 \%$ of total FDI stock since 2001). Advantages such as an excellent raw material base, a network of free trade associations' agreements, a long tradition of high-quality food production and strong regional brands are key reasons for world class multinational companies to direct M\&A activity towards Serbian companies operating in the food industry. Tadic et al. (2019) suggest that efficiency, innovation, quality and flexibility are critical profitability factors in the case of 200 companies operating in the Serbian food industry sector.

From the sustainability point of view, one should also add the fact that the Serbian law prohibits the production and import of any genetically modified (GMO) foods and seeds. It seems that the Serbian government has recognized the importance of food and agricultural sectors for the development of the whole country. However, even though above mentioned data could lead to a conclusion that Serbia has comparative advantages in the field of food sector, Momčilović et al. (2015) indicated that suitable circumstances for the sustainable growth were limited or there was no real sustainable growth in this sectors during the previous period. 
In the food industry, the highlight is a consolidation driven purchase of the Niška Mlekara by the largest sector player Imlek. In addition, the Serbian food concern Swisslion acquired the wine producer Vršački Vinogradi. Analysing the M\&A practice and trend in the Serbian food industry, at a first sight, a strong impact of sustainability considerations in the M\&A decision making and realization process is not observed. The trend in the food consumption recognized at the developed economies is also present in the Serbian market. Healthy conscious consumers prefer natural, non GMO food and environmentally friendly food alternatives. However, in the environment characterized by the low purchasing power, companies that operate in food industry are forced to decrease production costs and selling price of their goods. According to the official data published by the National Institute for Statistics (2019), the average family in Serbia has spent on food and non-alcoholic beverages $34.9 \%$ of the total family budget in 2018. The realization of operating synergy through the economy of scale effect appears to be the mean driving factor for M\&A in the Serbian food industry. However, during the last decade the investors begin to find sustainability much more worth and interesting than before.

In order to explore whether ESG issues play role in M\&A transactions, we used categorization given by Maloni and Brown (2006) who report about eight types of corporate social responsibility issues that can be understood as sustainability issues (SI) in the food industry as well: (SI1) animal welfare, (SI2) biotechnology (e.g. growth hormones or genetic testing), (SI3) health and safety (e.g. food safety, healthy lifestyles or local food sources), (SI4) environment, (SI5) labour and human rights (e.g. compensation, forced labour, child labour, training, education), (SI6) community, (SI7) fair trade, and (SI8) procurement (e.g. professional competence, confidentiality, disadvantaged suppliers, minority suppliers).

The analysis was conducted using a sample of 11 realized M\&A in the Republic of Serbia with the food producers as target companies. The analyzed transactions have been randomly elected and are classified as different legal types of M\&A: acquisition of asset, acquisition of shares, tender offer and merger/consolidation. The analysis was conducted using the data acquired from the annual reports and web sites of the target companies operating in the food and beverages sector involved in M\&A transactions.

\section{Results and Discussion}

The data presented in Table 1 show the way sustainability considerations have been factored into M\&A strategies, and prove weak relationship between sustainability and acquisition motives and moves. 
Table 1. Sustainability issues in M\&A in the Serbian food industry

\begin{tabular}{|c|c|c|}
\hline Acquirer & $\begin{array}{l}\text { Target } \\
\text { company }\end{array}$ & Possible sustainability issues considered by the acquirer \\
\hline $\begin{array}{l}\text { MK Group, } \\
\text { Belgrade }\end{array}$ & Carnex, Vrbas & $\begin{array}{l}\text { Socially responsible business, donatory activities, waste } \\
\text { management (SI4, SI6) }\end{array}$ \\
\hline $\begin{array}{l}\text { Delta Agrar, } \\
\text { Beograd }\end{array}$ & $\begin{array}{l}\text { Danubius d.o.o., } \\
\text { Novi Sad }\end{array}$ & $\begin{array}{l}\text { Danubis pata souses are completely natural, without artificial } \\
\text { colours, flavours and aditives (SI3) }\end{array}$ \\
\hline $\begin{array}{l}\text { Nektar d.o.o., } \\
\text { Backa Palanka }\end{array}$ & $\begin{array}{l}\text { Heba a.d., } \\
\text { Bujanovac }\end{array}$ & $\begin{array}{l}\text { Water production; promotion of a healthy life; emphasis on a } \\
\text { production safety management system (SI3) }\end{array}$ \\
\hline $\begin{array}{l}\text { Dijamant a.d., } \\
\text { Zrenjanin }\end{array}$ & $\begin{array}{l}\text { Kikindski mlin } \\
\text { a.d., Kikinda }\end{array}$ & $\begin{array}{l}\text { Commitment to caring for the environment and the maintenance } \\
\text { of product quality through the implementation of environmental } \\
\text { management systems (EMS) (SI3, SI4) }\end{array}$ \\
\hline $\begin{array}{l}\text { Trivit d.o.o. } \\
\text { Becej }\end{array}$ & $\begin{array}{l}\text { Klas doo, } \\
\text { Loznica }\end{array}$ & $\begin{array}{l}\text { Socially responsible business through employment of sensitive } \\
\text { groups of citizens (SI5, SI6, SI8) }\end{array}$ \\
\hline $\begin{array}{l}\text { Grand kafa } \\
\text { Beograd }\end{array}$ & $\begin{array}{l}\text { Soko Nada Stark } \\
\text { a.d., Beograd }\end{array}$ & $\begin{array}{l}\text { Socially responsible business; technological process is managed } \\
\text { in such a way to preserve the nutritional properties of natural raw } \\
\text { materials (SI2, SI3) }\end{array}$ \\
\hline $\begin{array}{l}\text { Dukat d.d, } \\
\text { Zagreb }\end{array}$ & $\begin{array}{l}\text { Somboled d.o.o., } \\
\text { Sombor }\end{array}$ & $\begin{array}{l}\text { Social responsibility through environmental protection, sponsorship } \\
\text { and donations and foodsafety and quality management (SI3, SI6) }\end{array}$ \\
\hline $\begin{array}{l}\text { Perutina Ptuj } \\
\text { d.d., Ptuj }\end{array}$ & $\begin{array}{l}\text { Topiko d.d., } \\
\text { Backa Palanka }\end{array}$ & $\begin{array}{l}\text { Product quality is the result of tradition, local farming and } \\
\text { controlled production on small farms and in natural environment } \\
\text { (SI3) }\end{array}$ \\
\hline $\begin{array}{l}\text { Frikom a.d, } \\
\text { Beograd }\end{array}$ & $\begin{array}{l}\text { Nova Sloga a.d., } \\
\text { Trstenik }\end{array}$ & $\begin{array}{l}\text { Mineral water as final product; promotion of a healthy life, fruit } \\
\text { and vegetables consumption (SI3) }\end{array}$ \\
\hline $\begin{array}{l}\text { Galus doo, } \\
\text { Pančevo }\end{array}$ & $\begin{array}{l}\text { Soya Food, } \\
\text { Lokve }\end{array}$ & $\begin{array}{l}\text { Soya Food products are made from non-GM soy, completely } \\
\text { natural, without artificial colours, flavours and aditives (SI2, SI 3) }\end{array}$ \\
\hline Swiss Lion & $\begin{array}{l}\text { PIK Takovo } \\
\text { Gornji } \\
\text { Milanovac }\end{array}$ & $\begin{array}{l}\text { Socially responsible business; top quality row materials; care for } \\
\text { employees (SI4, SI5, SI6) }\end{array}$ \\
\hline
\end{tabular}

Source: Author's presentation

Two types of acquisitions could be distinguished. One type enables the acquirer to build the presence in the key segments with sustainability products in line with modern health trends (for example, the target company is producing mineral water, or has plant-based production). Industry of frozen food FRIKOM ad Beograd acquisition of Nova sloga Trstenik, a company specialized in mineral water production (brand $\mathrm{Mg}$ Mivela), is just one of the latest M\&A deals at Serbian capital market that suggests that sustainability cares in the Serbian food and beverage industry. By taking over Nova sloga, Frikom has underlined its strategic priorities to build the portfolio which is in line with modern health trends. Following the classification given by Maloni and Brown (2006), the most important for these transactions are SI2 are SI3.

The other type of M\&As are those that help the buyer to improve synergies and consolidate leadership positions by acquiring targets with a recognized sustainability profile and credibility. An example of such a strategy is the acquisition of Somboled a.d. Sombor, a company that tracks social responsibility reputations by environmental protection, sponsorship and donations, food safety and quality management, by Dukat, dd Zagreb. The crucial categories of sustainability issues for these M\&A deals are SI5, SI6 and SI8. 
Understanding the relationship between sustainability and acquisition motives among the Serbian M\&As is particularly important taking into account the value creation chain in the food sector, with food processing companies as decisive players. Since food producers influence both agriculture as upstream, and retail and consumers as downstream links within the chain, and vice versa, the way sustainability issues are perceived by those companies and their growth strategies is partly impacted by the level of the sustainability in the whole value creation chain. Thus, taking into account a high concentration in the Serbian retail sector and the low purchasing power of end consumers, there are obviously limited opportunities for sustainability improvements of the food products. On the other side, a state of the development of the Serbian sustainable agriculture describes the supply side for the sustainable products and explain a moderate intensity of this M\&A driver in the Serbian food industry.

Regarding sustainability consideration in the M\&A transactions, in the food industry and generally, Serbian companies need to continually cope with the growing expectations of the stakeholders by including the sustainability issues in their strategies, operative management and reporting systems. It should be pointed out that the new regulation (Law on Accounting, Official Gazette of the Republic of Serbia No. 62/2013, 30/2018, $73 / 2019$ ) brings additional requirements for large companies (500 or more employees) in the field of non-financial reporting. Such companies are now required to include some sustainability issues in their annual reports (Article 37). In our opinion, this will increase transparency and improve sustainability due diligence process of M\&A transactions at the Serbian capital market.

\section{Conclusions}

The paper explored key areas in which environmental, social and governance issues may play important role in M\&A transactions, with a particular emphasis on the food industry in the Republic of Serbia. The study has answered the research questions concerning the role and the pattern of the sustainability issues in the case of M\&A in the Serbian food industry. By doing so, it reveals some important messages for companies involved in M\&A deals, capital market institutions, consumers, society and policy makers.

Firstly, regardless of the underlying realization motive, companies involved in M\&A should be better prepared by addressing sustainability issues early in the process, i.e. during the section of target company, due diligence process and transaction valuation. Acquiring companies should not neglect the importance of sustainability issues during the post-acquisition integration too.

Secondly, while defining and realizing M\&A strategy, companies operating in food industry, should adjust their existing portfolios in order to meet long-term changes in consumer tastes in relation to health and wellness trends, and sustainability. M\&A in the food industry are becoming strategic investments less concerned to generate high returns in the short run. 
Thirdly, a strong impact of sustainability considerations in the Serbian food industry (such animal welfare, biotechnology, health and safety, environment, labour and human rights or community) cannot be observed.

Finally, two prevailing types of M\&A in the Serbian food industry could be distinguished. The sustainability issue that has moved to the forefront in the first M\&A type are those related to biotechnology, modern health trends and safety. The other type of M\&A deals helps the buyer to gain sustainability synergies by acquiring target with a recognized sustainability profile and credibility obtained by engaging for community and labour and human rights.

However, it is important to underline that the M\&A activity in the Serbian food industry present in the last two decades might lead to some unfavourable impacts on the society, environment and the governance. These negative consequences from the sustainability point of view are related to a lowering of the level of competition in the food sector, loss for small and medium sized food producers, barriers to entry for new producers and lack of transparency for food consumers. Creating synergies through M\&A is glamorous, but integrating sustainability issues is difficult and disturbs Serbian managers who are mainly seeking to create synergies by cutting costs. Sustainability and responsibility are often, unfortunately, far from their point of interest.

\section{Conflict of interests}

The authors declare no conflict of interest.

\section{References}

1. Bonny, S. (2017). Corporate Concentration and Technological Change in the Global Seed Industry. Sustainability, 9(9), 1632. doi:10.3390/su9091632

2. Caiazza, R., \& Volpe, T. (2015). M\&A process: a literature review and research agenda. Business Process Management Journal, 21(1), 205-220. doi: 10.1108/ BPMJ-11-2013-0145

3. Clapp, J. (2018). Mega-Mergers on the Menu: Corporate Concentration and the Politics of Sustainability in the Global Food System. Global Environmental Politics, 18(2), 12-33. doi: 10.1162/glep_a_00454

4. Cooper, B. (2018). How sustainability is influencing M\&A in the food industry. Just-Food, Aroq Ltd, Retrieved from https://www.just-food.com/analysis/howsustainability-is-influencing-ma-in-the-food-industry_id137781.aspx (July 10, 2019)

5. Deloitte (2008). How Green is the Deal? The Growing Role of Sustainability in $M \& A$. Retrieved from https:/www2.deloitte.com/content/dam/Deloitte/il/ Documents/risk/CCG/other_comittees/how_green_is_the_deal_deloitte_102408. pdf (June 15, 2018) 
6. Denčič-Mihajlov, K. \& Spasić, D. (2018). Mergers and acquisition as competitive strategies in the digitalization era. In: Strategic Management and Decision Support Systems in Strategic Management (pp. 47-53), Subotica: Ekonomski fakultet (in Serbian: Merdžeri i akvizicije kao konkurentske strategije u eri digitalizacije).

7. Denčić-Mihajlov, K. \& Stojanović Blab, M. (2017). Sustainability Reporting Trends in Regulation and Challenges in Implementation. In Michalke, A., Rambke, M. \& Zeranski, S. (Eds.), Vernetztes Risiko- und Nachhaltigkeitsmanagement Erfolgreiche Navigation durch die Komplexität und Dynamik des Risikos (pp. 2742), Wiesbaden: Springer Gabler. Doi: 10.1007/978-3-658-19684-4_4

8. Denčić-Mihajlov, K.\&Zeranski,S. (2017). Development of sustainability indicators: approaches, challenges and opportunities. FACTA UNIVERSITATIS, Series: Economics and Organization, 14(4), 291 - 306. doi: 10.22190/FUEO1704291D

9. Development Agency of Serbia (2017). Agriculture, Food and Beverages. Retrieved from https://ras.gov.rs/en/agriculture-food-and-beverages (September 2, 2019)

10. FoodDive. (2015). Top 10 food and beverage industry trends - and why they matter. Retrieved from https://www.fooddive.com/news/top-10-food-and-beverageindustry-trends-and-why-they-matter/404484/ (August 1, 2019)

11. Hečková, J., Štefko, R., Frankovský, M., Birknerová, Z., Chapčáková, A. \& Zbihlejová, L. (2019). Cross-Border Mergers and Acquisitions as a Challenge for Sustainable Business. Sustainability, 11(11), 3130. doi: 10.3390/su11113130

12. IMAA. (2017). M\&A Statsitics. Retrieved from https://imaa-institute.org (May 3, 2019)

13. Law on Accounting, Official Gazette of the Republic of Serbia No 62/2013, 30/2018, 73/2019 - other law

14. Maloni, M. \& Brown, E. (2006). Corporate Social Responsibility in the Supply Chain: An Application in the Food Industry. Journal of Business Ethics, 68, 35-52.

15. Mannheimer Swartling. (2017). Sustainability in M\&A transactions. Retrieved from https://www.mannheimerswartling.se/en/news/in-focus/sustainability-in-matransactions/ (May 5, 2019)

16. Manocha, P., Srai, J., \& Kumar, M. (2016). Understanding the role of Sustainability in Mergers \& Acquisitions from the perspective of Supply Chain Management - How green is the deal? Paper presented at the 20th Cambridge International Manufacturing Symposium, retrieved from: https://doi.org/10.17863/CAM.6150

17. Momčilović, M., Begović-Vlaović, S., Tomašević, S. \& Ercegovac, D. (2015). Sustainable Growth Rate: Evidence from Agricultural and Food Enterprises. Management, 76, 63-75. 
18. Price Waterhouse Coopers. (2012). The integration of environmental, social and governance issues in mergers and acquisitions transactions. Retrieved from https:// www.pwc.com/gx/en/sustainability/publications/assets/pwc-the-integrationof-environmental-social-and-governance-issues-in-mergers-and-acquisitionstransactions.pdf (April 3, 2019)

19. Saat, M. \& Himmelsbach, J. (2014). Sustainable Merger and Acquisition Transactions - Important Aspects as Part of a Process Model Especially for Enterprises in the Service Market. International Journal of Business and Social Science, 5 (1), 65-74.

20. Schmidt-Riediger, B. (2008). Sustainability Marketing in the German Food Processing Industry (Unpublished doctoral dissertation). Technical University of Munich, Munich, Germany.

21. Statistical Office of the Republic of Serbia. (2019). Household Budget Survey. Survey no. 072 - LXIX (in Serbian: Nacionalni zavod za statistiku. (2019). Anketa o potrošnji domaćinstva, Sopštenje br. 072 - god. LXIX) (March 3, 2019)

22. Tadić, J., Jevtić, J. \& Jančev, N. (2019). Modeling of critical profitability factors: Empirical research from food industry in Serbia. Economics of Agriculture, 66(2), 411-422. doi: 10.5937/ekoPolj1902411T

23. Todorović, E. \& Denčić-Mihajlov, K. (2004). Acquisition as a type of foreign direct investment in the Republic of Serbia. Economics of Enterprise, 52(3-4), 106-114. (In Serbian: Akvizicija kao oblik stranih direktnih investicija u privredu Republike Srbije. Ekonomika preduzeća, 52(3-4), 106-114)

24. UNCTAD. (2019). World Investment Report. Retrieved from http://unctad.org/en/ PublicationsLibrary/wir2017 en.pdf(June 10, 2019)

25. World Bank Report (2019). Country Report Serbia. Retrieved from: https://data. worldbank.org/country/serbia (June 5, 2019)

26. World Economic Forum. (2016). The Global Risks Report. Retrieved from: http:// www3.weforum.org/docs/GRR/WEF_GRR16.pdf (April 3, 2019) 